\title{
STEROID HORMONE PRODUCTION BY SHEEP OVARIAN FOLLICLES CULTURED IN VITRO
}

\author{
R. F. SEAMARK, * R. M. MOOR AND J. E. A. MaINTOSH \\ Agricultural Research Council Unit of Reproductive Physiology and Biochemistry, \\ University of Cambridge, 307 Huntingdon Road, Cambridge CB3 07Q
}

(Received 22nd March 1974)

Summary. Large intact follicles and granulosa cells were obtained from sheep ovaries at various stages of the oestrous cycle and were cultured in vitro for 7 days. The daily output of steroid hormones into the culture medium was determined using a procedure capable of measuring a wide range of steroids including immunoreactive oestrogen, testosterone,

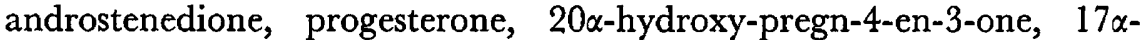
hydroxyprogesterone, $17 \alpha, 20 \alpha$-dihydroxy-pregn-4-en-3-one, pregnenolone, $17 \alpha$-hydroxypregnenolone and certain hydrogenated metabolites.

Intact follicles explanted from sheep on Day 4 of the cycle produced oestrogen ( $40 \mathrm{ng} / \mathrm{mg}$ follicular tissue per $24 \mathrm{hr}$ ) during the first 3 days in culture followed by large amounts of testosterone $(100 \mathrm{ng} / \mathrm{mg}$ per $24 \mathrm{hr}$ ) and finally $17 \alpha$-hydroxylated progestin. Follicles explanted at midcycle produced constant amounts of oestrogen (30 ng/mg per $24 \mathrm{hr}$ ) throughout the culture period; no other steroids were produced in significant quantities. The highest levels of oestrogen $(75 \mathrm{ng} / \mathrm{mg}$ per $24 \mathrm{hr}$ ) were produced by follicles which had been explanted from sheep on Day 14 of the cycle. Oestrogen production declined rapidly in follicles explanted just before oestrus (late Day 15) and was replaced by the production of testosterone and 17 $\alpha$-hydroxylated progestin. The production of oestrogen and testosterone was very low in follicles explanted at oestrus; these follicles produced a transient peak of $17 \alpha$-hydroxypregnenolone $(30 \mathrm{ng} / \mathrm{mg}$ per $24 \mathrm{hr}$ ) followed by large amounts of progesterone (300 ng/mg per $24 \mathrm{hr}$ ) and $20 \alpha$-hydroxy-pregn-4-en-3-one (250 ng/mg per $24 \mathrm{hr}$ ).

Monolayer cultures of granulosa cells produced only progesterone, $20 \alpha$-hydroxy-pregn-4-en-3-one and pregnenolone, thus implicating the cells of the theca interna as the principal source of oestrogen, androgen and $17 \alpha$-hydroxylated progestin.

Our findings indicate that the biosynthesis of oestrogen in the cells of the theca interna involve a sequence of steps including pregnenolone $\longrightarrow 17 \alpha$-hydroxypregnenolone $\longrightarrow 17 \alpha$-hydroxyprogesterone $\longrightarrow$ testosterone or androstenedione $\longrightarrow$ oestrogen. During the transformation of follicles from oestrogen to progesterone secretors, steroid synthetic

* Present address: Department of Obstetrics and Gynaecology, The University of Adelaide, Adelaide, South Australia 5000. 
capacity is transferred from the theca interna to the membrana granulosa. The accumulation first of testosterone and then of $17 \alpha$-hydroxypregnenolone suggests that the aromatase and then the desmolase systems limit steroid production in the theca interna during the period of transformation.

\section{INTRODUCTION}

Oestrogen is secreted by the ovaries of sheep in a characteristic pattern throughout the oestrous cycle (Cox, Mattner \& Thorburn, 1971). The output of this steroid is low during the mid-luteal phase of the cycle, increases to a maximum level just before oestrus and then declines abruptly soon after the commencement of oestrus. A similar pattern of oestrogen production occurs when large intact follicles are dissected free of stromal tissue and are maintained in organ culture (Moor, 1973). The fact that isolated follicles retain not only their biosynthetic capacity but also their morphological integrity in culture provides the investigator with an acceptable in vitro system in which to study the endocrine function of individual follicles.

The aims of the present study were threefold, namely to characterize the range and sequence of steroids produced by large follicles, to define the cellular origin of these steroids, and to gain insight into the dynamic aspects of follicular steroid regulation. To meet these objectives, it has been necessary to ascertain, in detail, the changes that occur amongst the several dynamically interrelated steroids that act as substrates for key enzymes in follicular steroidogenesis. The rapid yet sensitive multisteroid analytical system, developed for this purpose, is included in this paper.

\section{MATERIALS AND METHODS}

\section{Culture of ovarian follicles}

The ovaries were removed from Welsh Mountain sheep on Day 4, 8, 14 or 15 of the cycle, or 12 to $18 \mathrm{hr}$ after the onset of oestrus (Table 1). The largest follicle from each was dissected free of surrounding stromal tissue and cultured individually in a plastic culture dish using techniques already described (Moor, Hay, McIntosh \& Caldwell, 1973). Large follicles from two additional sheep on Days 4 and 14 of the cycle, respectively, were opened and suspensions of granulosa cells were obtained. These cells were maintained at $37^{\circ} \mathrm{C}$ as monolayer cultures in plastic culture dishes in a moist atmosphere consisting of $5 \% \mathrm{CO}_{2}$ in air. The culture medium was the same as that used for the intact follicles with the exception that LH (NIH-LH-S17, $5 \mu \mathrm{g} / \mathrm{ml}$ medium) was added to half the granulosa cell cultures. The medium from both the intact follicles and from the granulosa cell cultures was changed daily; the old medium, after withdrawal from the culture dish, was rapidly frozen and stored at $-20^{\circ} \mathrm{C}$ until required for steroid analysis. Steroid hormone production by the follicles was monitored daily by analysis of the culture medium.

\section{Steroid assay procedure}

The assay procedure is outlined in Flow-sheets $1(\mathrm{a})$ and $1(\mathrm{~b})$. The assay was 
designed to obtain measures of the output of the following steroids, the trivial names of which are included in parentheses: immunoreactive oestrogen; testosterone; androst-4-en-3,17-dione (androstenedione); $17 \beta$-hydroxy-5 $\alpha$ androstan-3-one (5 $\alpha$-dihydrotestosterone); $3 \beta$-hydroxy-androst-5-en-17-one (dehydroepiandrosterone); $3 \beta$-hydroxy-pregn-5-en-20-one (pregnenolone); 17 $\alpha$-hydroxypregnenolone; progesterone; 17 $\alpha$-hydroxyprogesterone; $20 \alpha-$ hydroxy-pregn-4-en-3-one; plus certain hydrogenated derivatives including $5(\xi)$-pregnane-3,20-dione (pregnanedione), 5( $\xi)$-pregnane-3( $\xi), 20 \alpha$-diol

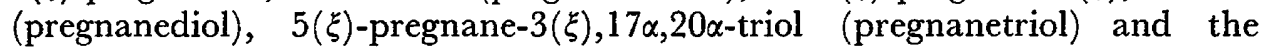
$5(\xi)$-androstane- $3(\xi), 17 \beta$-diol(androstanediol) and androst-5-en-3 $\beta, 17 \beta$-diol (androstenediol) fraction.

Portions of the medium from each follicle were assayed separately for $\mathrm{C}_{18}$ (oestrogens), $\mathrm{C}_{19}$ (androgens) and $\mathrm{C}_{21}$ (progestins) steroids. Aliquots of medium $(0.2$ to $0.4 \mathrm{ml})$ obtained from the cultures with follicles (or without follicles as controls) were equilibrated for $5 \mathrm{~min}$ at $25^{\circ} \mathrm{C}$ with ${ }^{3} \mathrm{H}$-labelled tracer amounts (2000 to $3000 \mathrm{ct} / \mathrm{min}$ ) of the steroids to be assayed, as internal recovery standards. The mixtures were then extracted twice with 2-ml vols of diethyl ether, freezing being used to facilitate complete separation of the phases.

The immunoreactive oestrogens were assayed directly by radioimmunoassay (Moor et al., 1973). Other steroids were isolated by thin-layer chromatography (TLC) on silica gel plates (Polygram SIL N-HR/UV ${ }_{254}$; Machery-Nagel \& Co., Duren, West Germany) which were washed before use in ethyl acetate. Radioactive markers and coloured dyes (sudan black and eosin) to facilitate the localization of samples were included. After development (toluene:methanol, $95: 5(\mathrm{v} / \mathrm{v}) ; 19$ to $\left.20^{\circ} \mathrm{C}\right)$, the radioactive markers were detected by cutting the strip into sections. The steroids were eluted by transferring the appropriate portion of each strip to a tube containing $0.2 \mathrm{ml}$ water and extracting twice with $2-\mathrm{ml}$ vols of diethyl ether.

To facilitate the separation of progesterone (and $5 \beta$-pregnanedione) from other substances present, material eluted from the appropriate area of the chromatogram was subjected to mild acetylation procedures $(0.2 \mathrm{ml}$ acetic anhydride: pyridine $(1: 1)$ was added to the residue, and the material was allowed to stand at room temperature for $15 \mathrm{hr}$ ) and the reaction products were purified by alumina chromatography (see 'Analytical methods, iv') before assay with corticosteroid-binding globulin (CBG; see 'Analytical methods, v').

Neither 20 $\alpha$-hydroxy-pregn-4-en-3-one nor 17 $\alpha$-hydroxyprogesterone were adequately resolved by TLC, so eluates of the area corresponding to the reference steroids were separated as follows.

For 20x-hydroxy-pregn-4-en-3-one, a portion of the eluate was allowed to react with the specific $20 \alpha$-hydroxysteroid dehydrogenase from fetal blood (Seamark, Herriot \& Nancarrow, 1972; see 'Analytical methods, ii') and the mass of progesterone so formed was then determined by CBG assay after chromatography on alumina. Another portion of the eluate was subjected to acetylation and the content of $17 \alpha$-hydroxyprogesterone was determined by CBG assay after alumina chromatography: 17 -hydroxyprogesterone was refractive to acetylation under the conditions chosen and was readily resolved from $20 \alpha$-acetoxy-pregn-4-en-3-one on the alumina columns. 
Flow-sheet 1. Schemes showing the separation of (a) $\mathrm{C}_{21}$ steroids and (b) $\mathrm{G}_{19}$ steroids by thin-layer chromatography, the method of enzymatic or chemical modification, and the isolation of products for assay using alumina chromato(a) graphy

Diethyl ether extract of sample + internal recovery standards

Thin-layer chromatography

Fraction isolated

Subsequent treatment

Product isolated and assayed

(1) $17 \alpha, 20 \alpha$-Dihydroxy-pregn-4-en-3-one $17 \alpha, 17 \alpha$-Dihydroxypregnenolone Pregnanediol

HSD, (Ac) $)_{2} \mathrm{O} \longrightarrow\{$ 17 $\alpha$-Hydroxyprogesterone + 17 $\alpha$-Hydroxypregnanedione Pregnanedione

(2) 17 -Hydroxypregnenolone

(3) 17 $\alpha$-Hydroxyprogesterone 20a-Hydroxy-pregn-4-en-3-one

(4) Pregnenolone $3 \beta$-Hydroxy-5 $\alpha$-pregnane-20-one $3 \alpha$-Hydroxy-5 $\beta$-pregnane-20-one $\}$

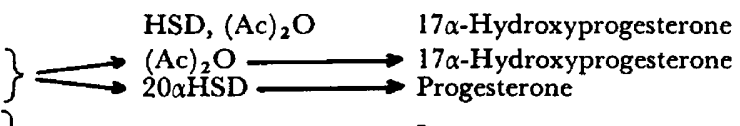

(5) $3 \beta$-Hydroxy-5 $\beta$-pregnane- 20 -one

(6) Progesterone

(7) 5( $\alpha, \beta)$-Pregnane-3,20-dione

$\mathrm{HSD},(\mathrm{Ac})_{2} \mathrm{O}$

$\mathrm{HSD},(\mathrm{Ac})_{2} \mathrm{O}$

$(\mathrm{AC})_{2} \mathrm{O}$

(Ac) ${ }_{2} \mathrm{O}$
Progesterone + $5 \beta$-Pregnanedione

5 $\beta$-Pregnane-3,20-dione Progesterone $5(\alpha, \beta)$-Pregnane-3,20-dione

$\mathrm{HSD}=$ hydroxysteroid dehydrogenase from Pseudomonas testosteronii; $20 \alpha \mathrm{HSD}=20 \alpha$-hydroxysteroid dehydrogenase from fetal blood; $(\mathrm{Ac})_{2} \mathrm{O}=$ exposure to mild acetylation conditions.

(b)

\begin{tabular}{|c|c|c|}
\hline \multicolumn{3}{|c|}{ Thin-layer chromatography } \\
\hline Fraction isolated & $\begin{array}{l}\text { Subsequent } \\
\text { treatment }\end{array}$ & Product isolated and assayed \\
\hline (1) $11 \beta$-Hydroxytestosterone & - & $11 \beta$-Hydroxytestosterone \\
\hline (2) Androstan(en)diol(s) & - & Androstan(en)diols \\
\hline (3) Testosterone & - & Testosterone \\
\hline $\begin{array}{l}\text { (4) Dehydroepiandrosterone } \\
3-\mathrm{Hydroxy}-5(\alpha, \beta) \text {-androstan-17. } \\
\text { one }(\mathrm{s})\end{array}$ & $\mathrm{IaBH}_{4}$ & $\begin{array}{l}\text { Androstan(en)diols } \\
\text { (i.e. } 17 \beta \text {-dehydro-derivatives) }\end{array}$ \\
\hline $\begin{array}{l}\text { 5a-Dihydrotestosterone } \\
\text { (5) Androstenedione }\end{array}$ & $\underset{\mathrm{NaBH}_{4}}{-}$ & $\begin{array}{l}5 \alpha \text {-Dihydrotestosterone } \\
\text { Testosterone }\end{array}$ \\
\hline
\end{tabular}

$\mathrm{NaBH}_{4}=$ reduction using sodium borohydride. 
For assay, pregnenolone and $17 \alpha$-hydroxypregnenolone were converted to their respective $\Delta^{4}$-oxosteroids, using the hydroxysteroid dehydrogenase prepared from Pseudomonas testosteronii (see 'Analytical methods, iii'), which contained $\Delta^{4-5}$ isomerase activity. The reaction products were subjected to acetylation and the refractive oxosteroids were assayed by CBG assay after chromatography on alumina.

The area of the chromatogram which would contain other $\mathrm{C}_{21}$ steroids, including pregnanediol and pregnanetriol, was eluted and the eluate was allowed to react with the bacterial hydroxysteroid dehydrogenase. The reaction products were then subjected to acetylation and the pregnanedione and $17 \alpha-$ hydroxy-pregnanedione fractions were purified by alumina chromatography: CBG assay of the material present in these two fractions provided an index of the concentrations of the pregnanediol and pregnanetriol fractions, respectively.

The $17 \alpha, 20 \alpha$-dihydroxy-pregn-4-en-3-one was estimated by allowing material eluted from thin-layer chromatograms containing this compound to react with the specific $20 \alpha$-hydroxysteroid dehydrogenase from fetal blood. The $17 \alpha$ hydroxyprogesterone formed was assayed by $\mathrm{CBG}$ after acetylation and alumina chromatography.

After alumina column chromatography, testosterone, $5 \alpha$-dihydrotestosterone and other $\mathrm{C}_{19}$-17-hydroxysteroid fractions, including androstane(en)diol and $11 \beta$-hydroxytestosterone, were assayed without modification using the testosterone-binding globulin (TBG) from human late pregnancy blood plasma (see 'Analytical methods, iv').

For assay, androstenedione, the dehydroepiandrosterone fraction and other $\mathrm{C}_{19}-17$-oxosteroids were converted to the corresponding $17 \beta$-hydroxysteroid by treatment with sodium borohydride $\left(\mathrm{NaBH}_{4}\right)$ at $4^{\circ} \mathrm{C}$ (Baird, 1968). The product was isolated by alumina chromatography and assayed using TBG.

\section{Analytical methods}

(i) Reagents. All solvents, including cyclohexane (BDH Chemicals Ltd, Dorset, U.K.) and ethanol (James Burrough Ltd, London, U.K.), were redistilled through a fractionating column before use. The $\mathrm{NAD}^{+}$and $\mathrm{NADP}^{+}$ were obtained from Sigma (London) Chemical Co. Ltd (Kingston-uponThames, Surrey, U.K.) and Triton X-100 from Fisons Scientific Apparatus (Leics., U.K.).

The $\left[1 \alpha, 2 \alpha(\mathrm{n})-{ }^{3} \mathrm{H}\right]$ testosterone $(40 \mathrm{Ci} / \mathrm{mmol}),\left[7(\mathrm{n})-{ }^{3} \mathrm{H}\right]$ androstenedione (3 $\mathrm{Ci} / \mathrm{mmol}), 17 \alpha$-hydroxy $\left[7(\mathrm{n})-{ }^{3} \mathrm{H}\right]$ progesterone (10 $\mathrm{Ci} / \mathrm{mmol}$ ), dehydro$\left[7(\mathrm{n})-{ }^{3} \mathrm{H}\right]$ epiandrosterone $(10 \mathrm{Ci} / \mathrm{mmol}), 17 \beta-\left[6,7-{ }^{3} \mathrm{H}\right]$ oestradiol $(40 \mathrm{Ci} / \mathrm{mmol})$ and $\left[1,2-{ }^{3} \mathrm{H}\right]$ cortisol $(40 \mathrm{Ci} / \mathrm{mmol})$ were obtained from The Radiochemical Centre (Amersham, Bucks., U.K.). The $20 \alpha$-hydroxy $\left[1,2-{ }^{3} \mathrm{H}\right]$ pregn-4-en-3-one $(40 \mathrm{Ci} / \mathrm{mmol})$ and $\left[1,2-{ }^{3} \mathrm{H}\right]$ progesterone $(40 \mathrm{Ci} / \mathrm{mmol})$ were the products of NEN Chemicals GmbH (Frankfurt, West Germany). The ${ }^{3} \mathrm{H}$-labelled $20 \alpha-$ hydroxypregnenolone was prepared by enzymatic reduction of $20 \alpha$-hydroxy$\left[1,2-{ }^{3} \mathrm{H}\right]$ pregn-4-en-3-one, utilizing the $20 \alpha$-hydroxysteroid dehydrogenase from ovine fetal blood (see below). The ${ }^{3} \mathrm{H}$-labelled androstenediol was formed from dehydro $\left[7(\mathrm{n})-{ }^{3} \mathrm{H}\right]$ epiandrosterone by reduction with $\mathrm{NaBH}_{4}$. All radioactive steroids were purified before use by means of TLGand alumina chromatography. 
The purity of the non-radioactive steroids, pregnenolone, testosterone (Steraloids Ltd, Croydon, Surrey, U.K.), dehydroepiandrosterone, 20 $\alpha$-hydroxypregn-4-en-3-one, 17 $\alpha$-hydroxyprogesterone (Schering A.G., Berlin, West Germany) and progesterone (Koch-Light Laboratories Ltd, Bucks., U.K.), were confirmed by both TLG and gas-liquid chromatography. Other nonradioactive steroids were obtained from The Medical Research Council's reference collection.

All glassware was sonicated immediately after use in 1\% RBS25 (Chemical Concentrates Ltd, London, U.K.), rinsed extensively with deionized water and then with ethanol.

(ii) Oxidation with $20 \alpha$-hydroxysteroid dehydrogenase. Fetal ovine red blood cells were separated from plasma by centrifugation and washed twice with 2 vols of $0.9 \% \mathrm{NaCl}$. The cells $(22 \mathrm{ml})$ were then lysed with $5 \mathrm{~mm}$-sodium phosphate

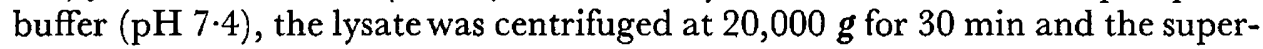
natant $(70 \mathrm{ml})$ was decanted. Solid $\left(\mathrm{NH}_{4}\right)_{2} \mathrm{SO}_{4}(14 \mathrm{~g})$ was added to the supernatant, the mixture was allowed to stand at $4^{\circ} \mathrm{C}$ for $2 \mathrm{hr}$ and was then centrifuged at $10,000 \mathrm{~g}$ for $10 \mathrm{~min}$. The supernatant $(7 \cdot 4 \mathrm{ml})$ was collected and $11 \cdot 1 \mathrm{~g}$ $\left(\mathrm{NH}_{4}\right)_{2} \mathrm{SO}_{4}$ were added. This mixture was left to stand overnight at 4 to $10^{\circ} \mathrm{C}$ and then centrifuged $(20,000 \mathrm{~g}$ for $30 \mathrm{~min})$. The supernatant was discarded and the precipitate was resuspended to $70 \mathrm{ml}$ in buffer. Small aliquots $(5 \mathrm{ml})$ were prepared and frozen.

To convert $\mathrm{C}_{21}-20 \alpha$-hydroxy to 20 -oxosteroids, the solvent was removed from a sample by evaporation at $45^{\circ} \mathrm{C}$ under a stream of air. One $\mathrm{ml}$ of a mixture containing NADP ${ }^{+}(0.5 \mu \mathrm{mol})$, nicotinamide $(10 \mu \mathrm{mol})$ and $40 \mu \mathrm{l}$ of the enzyme preparation in hydrogen carbonate buffer $(0.5 \mathrm{M}, \mathrm{pH} 9.2)$ was added. After being shaken gently, the mixture was incubated at $37^{\circ} \mathrm{C}$ for $30 \mathrm{~min}$ and the reaction products were extracted with diethyl ether.

(iii) Oxidation with non-specific hydroxysteroid dehydrogenase. Dried cells of Pseudomonas testosteronii (strain ATCG 11996) supplied by Sigma (London) Chemical Co., which had been grown on a medium containing testosterone, were used to prepare an extract as follows (Strott, Bermudez \& Lipsett, 1970). The freeze-dried cells $(0.25 \mathrm{~g})$ were placed in a small cellulose nitrate tube and mixed with $3.5 \mathrm{ml}$ enzyme medium containing $0.05 \mathrm{M}$-potassium phosphate buffer, $\mathrm{pH} 7 \cdot 0,3$ mm-EDTA, $0.05 \% \beta$-mercaptoethanol and $20 \%$ glycerol $(\mathrm{v} / \mathrm{v})$. The mixture was sonicated for $5 \mathrm{~min}$ at $0^{\circ} \mathrm{C}$ and centrifuged for $60 \mathrm{~min}$ at $20,000 \mathrm{~g}$. The supernatant was decanted into a screw-topped tube and after sufficient glycerol had been added to bring its concentration to $50 \%(\mathrm{v} / \mathrm{v})$ the extract was stored at $-16^{\circ} \mathrm{C}$.

For use, a portion of the extract was diluted $1: 50$ with the enzyme medium to which was added $1 \%$ bovine serum albumin; this could be stored for up to 1 month at $4^{\circ} \mathrm{C}$. A $0.5 \mathrm{ml}$ aliquot of a mixture containing pyrophosphate buffer $\left(20 \mathrm{~mm}, \mathrm{pH} 8.9\right.$ ) and $0.05 \mu \mathrm{mol} \mathrm{NAD}{ }^{+}$, and $20 \mu \mathrm{l}$ dilute enzyme solution were added to steroid residues and, after standing for $10 \mathrm{~min}$ at room temperature, the reaction products were extracted with diethyl ether.

(iv) Alumina column chromatography. Microcolumns of alumina $(3 \times 45 \mathrm{~mm})$ were prepared in glass columns made by fusing centrifuge tubes (to act as solvent reservoirs) to the tops of $2-\mathrm{ml}$ graduated pipettes. The alumina was retained with 
a glass bead and a plug of acid-washed sand. The aluminium oxide used, 'Camag' MFC 100-250 mesh (Hopkins \& Williams Ltd, Chadwell Heath, Essex, U.K.), was refluxed for 24 to $48 \mathrm{hr}$ over ethanol to remove possible impurities, dried in an air oven at $110^{\circ} \mathrm{C}$ for $15 \mathrm{hr}$ and cooled in a desiccator. For chromatography, $2.7 \%$ water (mass/mass) was added, an amount calculated to give half a monolayer on the active surface, and the alumina was mixed by tumbling in a sealed container for $12 \mathrm{hr}$. Extracts were transferred to the columns in cyclohexane containing $0.4 \%$ ethanol ( 2 vols of $2 \mathrm{ml}$ ). Elution was carried out with cyclohexane containing ethanol in the following concentrations. For the progestin-containing fractions; $2 \mathrm{ml}$ of $0.6 \%$ ethanol (pregnanedione and progesterone fraction), $3 \mathrm{ml}$ of $0.9 \%$ ethanol (discarded), and $3 \mathrm{ml}$ of $1.4 \%$ ethanol (17 $\alpha$-hydroxypregnanediol and $17 \alpha$-hydroxyprogesterone fraction). For the androgen-containing fractions; $3 \mathrm{ml}$ of $0.6 \%$ ethanol (androstenedione fraction) and $3 \mathrm{ml}$ of $2 \%$ ethanol (testosterone, $5 \alpha$-dihydrotestosterone and androstane(en)diol fraction).

(v) Competitive protein-binding assays. After the steroids had been extracted, separated and purified, they were assayed by competitive protein-binding methods (Murphy, 1967). The progestin assay used dog plasma transcortin (CBG), and the androgen assay used TBG from late human pregnancy blood plasma.

Two aliquots of extract were transferred to glass assay tubes $(12 \times 22 \mathrm{~mm})$ and the solvent was evaporated. The residues were taken up in $0.4 \mathrm{ml}$ of a mixture containing either dog plasma $(1.5 \%)$ and tritiated cortisol $(40 \mathrm{nCi} / \mathrm{ml})$ or pregnancy plasma $(0.8 \%)$ and tritiated testosterone $(40 \mathrm{nCi} / \mathrm{ml})$ in $0.05 \mathrm{~m}$ disodium tetraborate buffer (adjusted to $\mathrm{pH} 7.6$ with concentrated $\mathrm{HCl}$ ). The mixture was vortexed briefly and incubated for $20 \mathrm{~min}$ at $45^{\circ} \mathrm{G}$. The tubes were then transferred to a cold room $\left(4\right.$ to $\left.6^{\circ} \mathrm{C}\right)$ for at least $2 \mathrm{hr}$. From each tube, $0.3 \mathrm{ml}$ was transferred to small columns $(1 \times 3.5 \mathrm{~cm})$ containing $0.5 \mathrm{~g}$ Sephadex G-25 (fine) to separate free and protein-bound fractions. Elution was with $0.05 \mathrm{M}$-disodium tetraborate buffer, $\mathrm{pH} 7 \cdot 6$. The void volume $(0.5 \mathrm{ml})$ was discarded and the protein fraction $(1.2 \mathrm{ml})$ was collected directly into scintillation vials. Protein-bound radioactivity was determined after the addition of $10 \mathrm{ml}$ toluene-Triton scintillant (Triton X-100:toluene-PPO-POPOP scintillant, $4: 10(\mathrm{v} / \mathrm{v}))$. In all assays, the parallelism between the standard curve and the curve relating the values obtained from the two unequal sized aliquots of the extract assayed was examined as an additional check on the identity of the steroid determined. Appropriate allowance was made for recovery.

\section{Evaluation of assay procedure}

A detailed assessment was made only for those steroids of particular interest, namely progesterone, 17 $\alpha$-hydroxyprogesterone, 20 $\alpha$-hydroxy-pregn-4-en-3one, pregnenolone, 17 $\alpha$-hydroxypregnenolone, testosterone, androstenedione and dehydroepiandrosterone.

Specificity. The progestin-binding protein used is relatively non-specific as it reacts with a wide range of $\mathrm{C}_{21}$ steroids. Thus, in this assay the required degree of specificity was dependent upon TLC, the enzymatic conversion when used, the refractivity of the product to mild acetylation, and alumina chromatography. 
Significant interference in the pregnenolone assay by pregnanolones could occur and this problem remains unresolved.

Regarding the nature of the pregnanetriol fraction, on treatment with the specific $20 \alpha$-hydroxysteroid dehydrogenase only $50 \%$ of the fraction was conconverted to $17 \alpha$-hydroxyprogesterone-like material, the remainder presumably being $3 \beta$-hydroxy-5-dihydro derivatives. The 21 -hydroxylated compounds would not react in the assay as the 21-hydroxy group is not oxidized by the hydroxysteroid dehydrogenase and thus can be acetylated, the acetate formed being easily separated from $17 \alpha$-hydroxyprogesterone on the alumina columns.

The androgen-binding protein used reacts to some extent with most $17 \beta$ hydroxy $\mathrm{C}_{19(18)}$ steroids (Vermuelen \& Verdonck, 1970). Although there was no significant interference between the steroids investigated, as determined by assaying 100-ng amounts of each separately, there was considerable interference in the dehydroepiandrostene assay from steroids of the 3-hydroxy-5 $(\alpha, \beta)$ androstan-17-one series. In the procedure used, these 17-oxosteroids were chromatographed and converted on $\mathrm{NaBH}_{4}$ treatment, as was dehydroepiandrosterone, to reactive $17 \beta$ products.

Sensitivity. The assay blank for all steroids was less than $1 \mathrm{ng} / \mathrm{ml}$ as determined by assaying $0.4 \mathrm{ml}$ water. Results of assaying 0.2 to $0.4 \mathrm{ml}$ of medium from follicle-free cultures ranged from less than $0.1 \mathrm{ng} / \mathrm{ml}$ to $1.0 \mathrm{ng} / \mathrm{ml}$. Steroid concentrations reported below are corrected for the appropriate blank value.

Accuracy. Recovery of tritiated internal recovery standards ranged from 50 to $90 \%$. When known amounts of steroid, equivalent to $100 \mathrm{ng} / \mathrm{ml}$ of medium were added, recoveries after correction ranged from 86 to $107 \%$.

Precision. The intra-assay coefficient of variation (seven determinations on the same medium) was less than $12 \%$ for all steroids investigated.

\section{RESULTS}

The diameter and wet weight of each follicle and the morphological appearance of the theca interna and membrana granulosa are shown in Table 1. The wet weight of the follicular tissue was determined from a regression of wet weight on diameter; this regression was calculated by measuring the diameters of 174 follicles, puncturing them to remove the follicular fluid and immediately blotting and weighing each follicle. All the steroid results presented in this paper are expressed as ng steroid released into the culture medium $/ \mathrm{mg}$ follicular tissue per $24 \mathrm{hr}$.

After 7 days in culture, the cells of the theca interna were relatively small in all the follicles except those obtained from sheep early in the cycle. The theca interna of follicles explanted on Day 4 of the cycle was hypertrophied and was characterized by the presence of numerous enlarged cells. Little luteinization of the granulosa cells occurred in follicles explanted from untreated sheep ovariectomized between Days 4 and 15 of the cycle. By contrast, the membrana granulosa of follicles obtained at oestrus became heavily luteinized during the culture period.

The daily production of steroids by each cultured follicle is shown in Text-figs 
1 and 2. The results have been divided into groups according to the stage of the cycle at which the follicles were explanted.

It can be seen from Text-fig. 1 that oestrogen production by the largest follicle present in the ovary 4 days after oestrus declined during the first 2 to 3 days in culture. This decline was associated with a sharp rise in the release of testosterone and the other androgens followed by increasing levels of the $17 \alpha-$ hydroxylated progestins. By contrast, follicles explanted on Day 8 of the cycle continued to produce oestrogen at a high level throughout the 7-day culture period and only trace amounts of other steroids. Follicles explanted in the follicular phase of the cycle (Days 14 or 15) failed to sustain this high output of oestrogen in culture; as the production of oestrogen declined, there was a rise in the levels of both androgens and 17 $\alpha$-hydroxylated progestins. Follicles explanted at oestrus produced almost no oestrogens or androgens after the 1st day in culture. Steroid production by these follicles was characterized by high

Table 1. The physical and morphological characteristics of the sheep ovarian follicles used in the experiment

\begin{tabular}{|c|c|c|c|c|c|}
\hline \multirow{2}{*}{$\begin{array}{l}\text { Follicle no. } \\
\text { and symbol used } \\
\text { in Text-figs }\end{array}$} & \multirow{2}{*}{$\begin{array}{l}\text { Stage of cycle } \\
\text { at explantation }\end{array}$} & \multirow{2}{*}{$\begin{array}{l}\text { Diameter of } \\
\text { follicle }(m m)\end{array}$} & \multirow{2}{*}{$\begin{array}{l}\text { Wet wt* } \\
\text { of follicular } \\
\text { tissue (mg) }\end{array}$} & \multicolumn{2}{|c|}{$\begin{array}{c}\text { Morphology of follicle after } \\
7 \text { days in culture }\end{array}$} \\
\hline & & & & Theca interna & Membrana granulosa \\
\hline $\begin{array}{l}1(0) \\
2(\Delta) \\
3(\square) \\
4(\nabla) \\
5(\mathbf{\nabla}) \\
6(\bullet) \\
7(\nabla) \\
8(\bullet) \\
9(\Delta) \\
10(0)\end{array}$ & $\begin{array}{l}\text { Day } 4 \\
\text { Day } 4 \\
\text { Day } 4 \\
\text { Day } 8 \\
\text { Day } 8 \\
\text { Day } 14 \\
\text { Day } 15 \\
\text { Oestrus } \\
\text { Oestrus } \\
\text { Oestrus }\end{array}$ & $\begin{array}{l}5 \cdot 9 \\
5 \cdot 7 \\
6 \cdot 9 \\
8 \cdot 0 \\
5 \cdot 9 \\
8 \cdot 1 \\
6 \cdot 9 \\
7 \cdot 1 \\
7 \cdot 8 \\
6 \cdot 9\end{array}$ & $\begin{array}{l}13 \\
11 \\
17 \\
23 \\
13 \\
24 \\
17 \\
18 \\
22 \\
17\end{array}$ & $\begin{array}{l}\text { Hypertrophied } \\
\text { Hypertrophied } \\
\text { Hypertrophied } \\
\text { Regressed } \\
\text { Hypertrophied } \\
\text { Regressed } \\
\text { Regressed } \\
\text { Regressed } \\
\text { Regressed } \\
\text { Regressed }\end{array}$ & $\begin{array}{l}\text { No luteinization } \\
\text { Partial luteinization } \\
\text { Partial luteinization } \\
\text { No luteinization } \\
\text { No luteinization } \\
\text { Partial luteinization } \\
\text { Partial luteinization } \\
\text { Heavy luteinization } \\
\text { Heavy luteinization } \\
\text { Heavy luteinization }\end{array}$ \\
\hline
\end{tabular}

* Wet weight of tissue (excluding follicular fluid) calculated from non-linear regression of wet weight on diameter.

levels of progestin. There was a marked rise in the production of progesterone and $20 \alpha$-hydroxy-pregn-4-en-3-one, neither of which was evident in cultures of follicles explanted at any other stage of the cycle.

To identify the cellular origins of follicular steroids, it would be desirable to culture each cell type separately. Cultures of theca interna cells are, however, almost invariably contaminated by granulosa cells. We have therefore limited our study to steroid production by cultures of granulosa cells which can be isolated free from thecal elements. Granulosa cells were obtained from a large follicle on Day 4 and from another on Day 14 of the cycle. The monolayers of granulosa cells prepared from the two follicles produced only progesterone, $20 \alpha$-hydroxy-pregn-4-en-3-one and pregnenolone; no significant amounts of any of the $17 \alpha$-hydroxylated progestins, androgens or oestrogens were secreted. By adding LH to the culture medium, the levels of progesterone, 20 $\alpha$-hydroxypregn-4-en-3-one and pregnenolone were increased but no other steroids were produced. On the basis of these observations and for additional reasons pre- 
Day of cycle at explantation
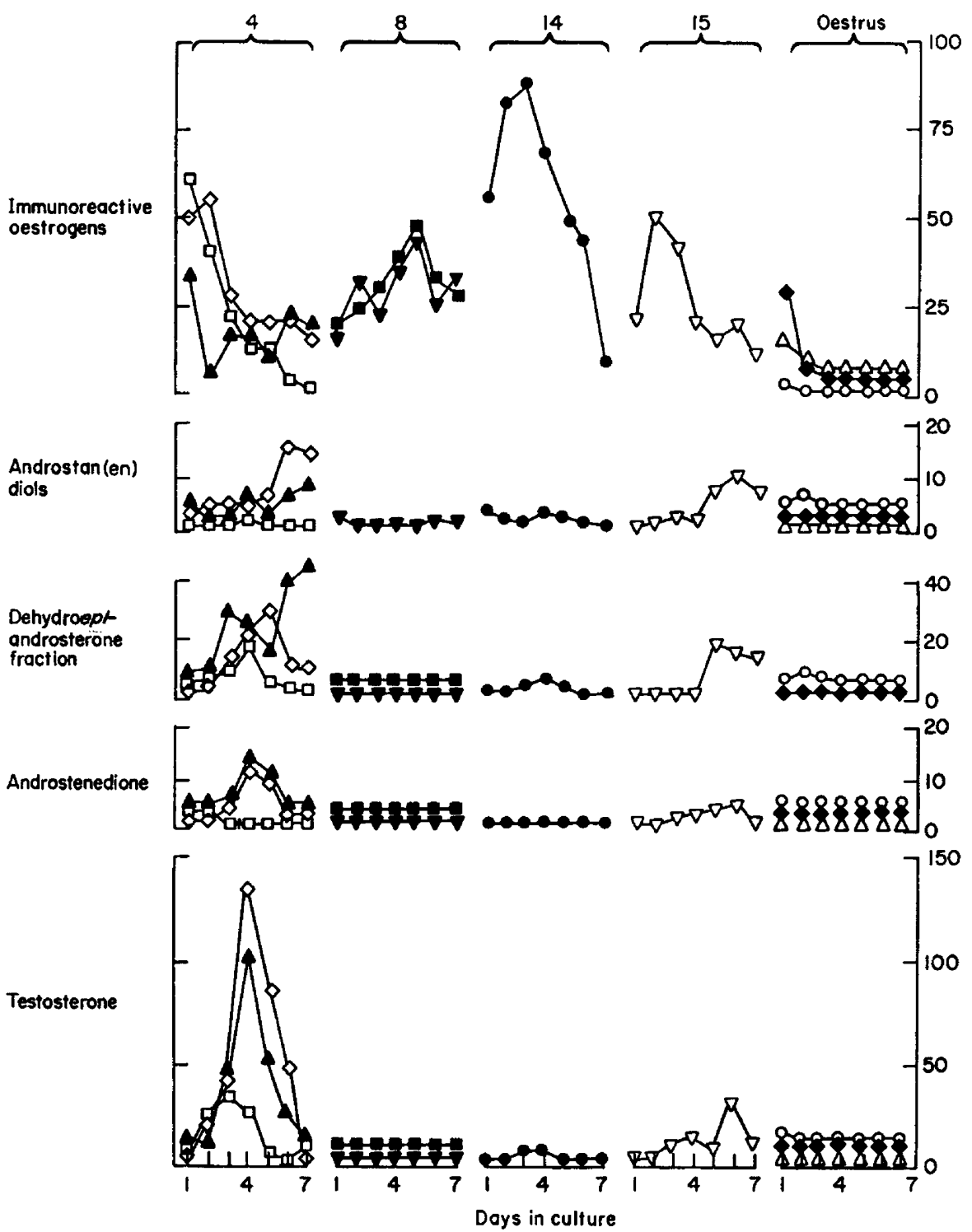

TEXT-FIG. 1. Rate of production of immunoreactive oestrogens and $\mathrm{C}_{19}$ androgens released into the culture medium by individual ovarian follicles explanted from sheep at different stages of the oestrous cycle and maintained in organ culture for 7 days. Each symbol represents an individual follicle; for key, see Table 1. 
Day of cycle at explantation
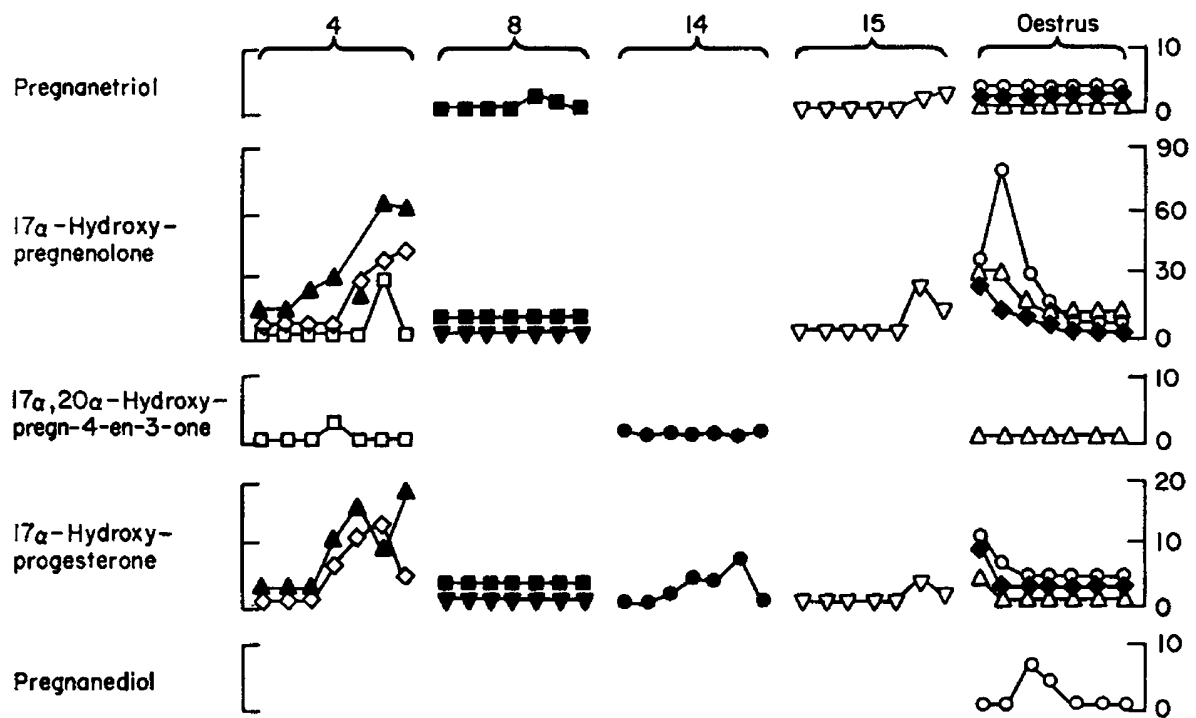

Pregnanediol $\quad[$
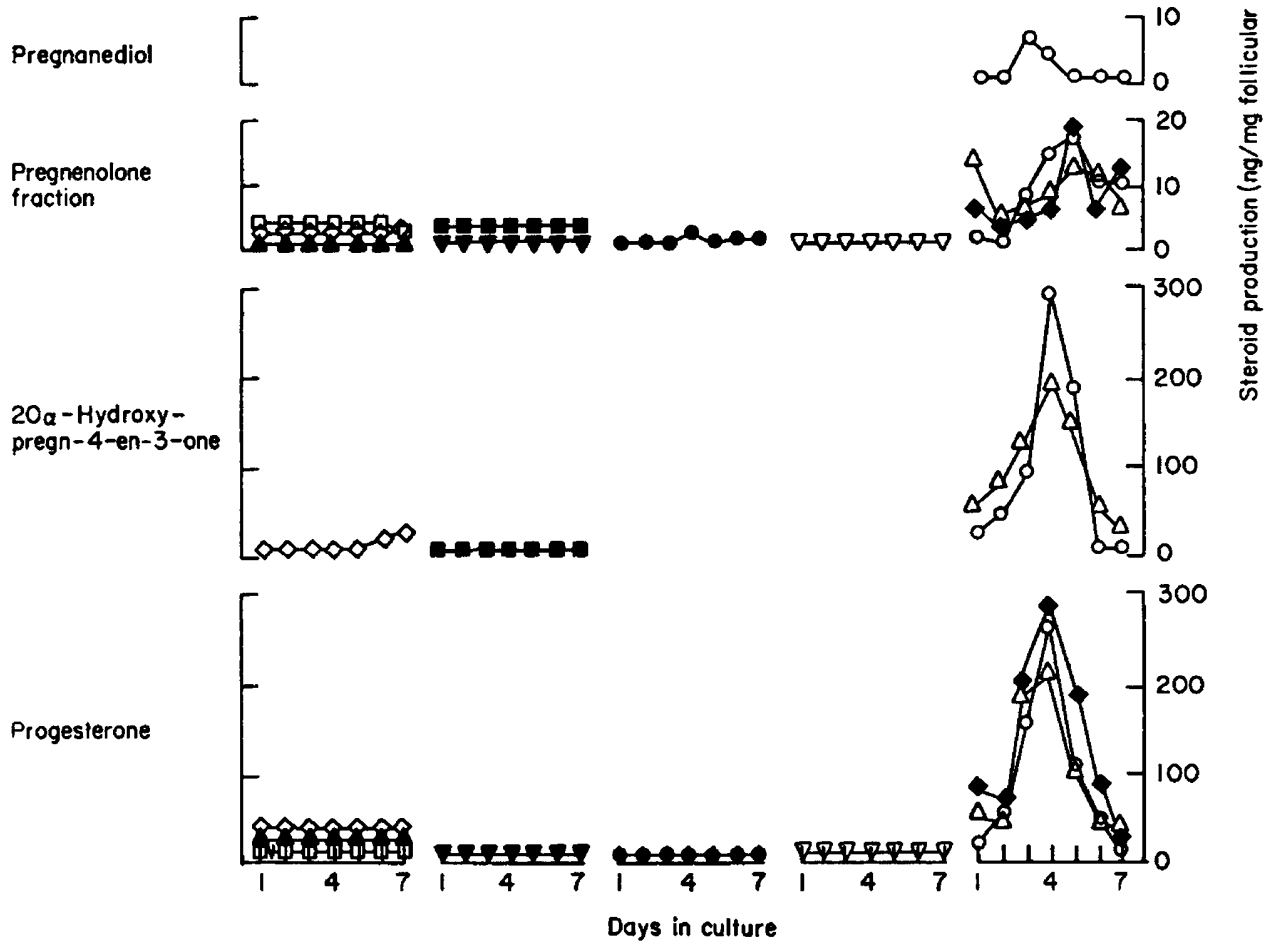

TEXT-FIG. 2. Rate of production of $\mathbf{C}_{21}$ progestins released into the culture medium by individual ovarian follicles explanted from sheep at different stages of the oestrous cycle and maintained in organ culture for 7 days. Each symbol represents an individual follicle; for key, see Table 1 . 
sented in the Discussion, we have divided the major steroids into two groups, the first consisting of progesterone, 20 $\alpha$-hydroxy-pregn-4-en-3-one and pregnenolone and referred to as 'granulosa steroids', and the second consisting of oestrogens, androgens and 17 $\alpha$-hydroxylated progestins and designated as 'thecal steroids'.

To gain insight into changes in the enzyme capacity of thecal cells at the various stages of the oestrous cycle, we have expressed the 'thecal steroid' content in terms of its potential to act as substrate for one or other of the key enzymes involved in oestrogen synthesis by the follicle (Text-fig. 3). The total

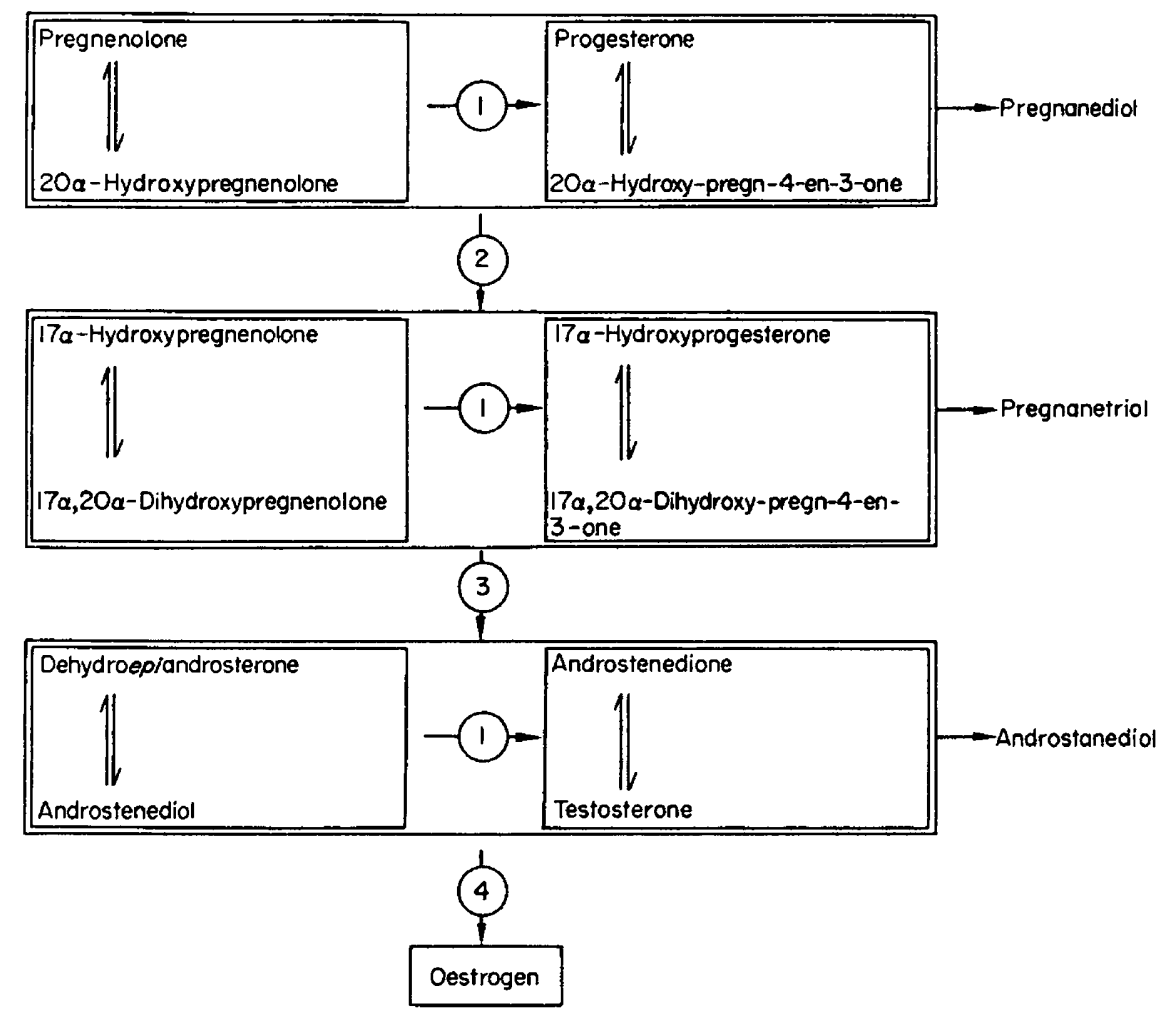

TEXT-FIG. 3. Presumed interrelationships of ovarian steroids, their metabolites and the major enzymes involved in follicular steroidogenesis. Figure numbers refer to enzyme systems: 1 , isomerase; $2,17 \alpha$-hydroxylase; 3 , desmolase $\left(\mathrm{C}_{21-19}\right.$ lyase $) ; 4$, aromatase. Systematic names of steroids are given in the text.

thecal steroid production on each day was calculated (Text-fig. 4a) and, by combining the levels of the appropriate steroids, the available substrate for each enzyme system, expressed as a percentage of total substrate, was determined for each day in culture. The results of these calculations for the follicles explanted from sheep at different stages of the cycle are shown in Text-figs 4(b) to 4(f), together with values for oestrogen, also expressed as a percentage of total thecal steroid produced.

There was a marked change in the pattern of steroid production during the 
period in culture by follicles explanted on Day 4 of the cycle (Text-figs 1 and 2). The production of substrate for aromatase activity increased as the level of oestrogen declined (Text-fig. 4b). After a period of high androgen production, substrate for the desmolase and isomerase systems began to accumulate.

Follicles explanted on Day 8 of the cycle produced only oestrogen (Text-fig. 4c). Follicles harvested on Days 14 and 15 of the cycle (Text-figs $4 \mathrm{~d}$ and 4e)

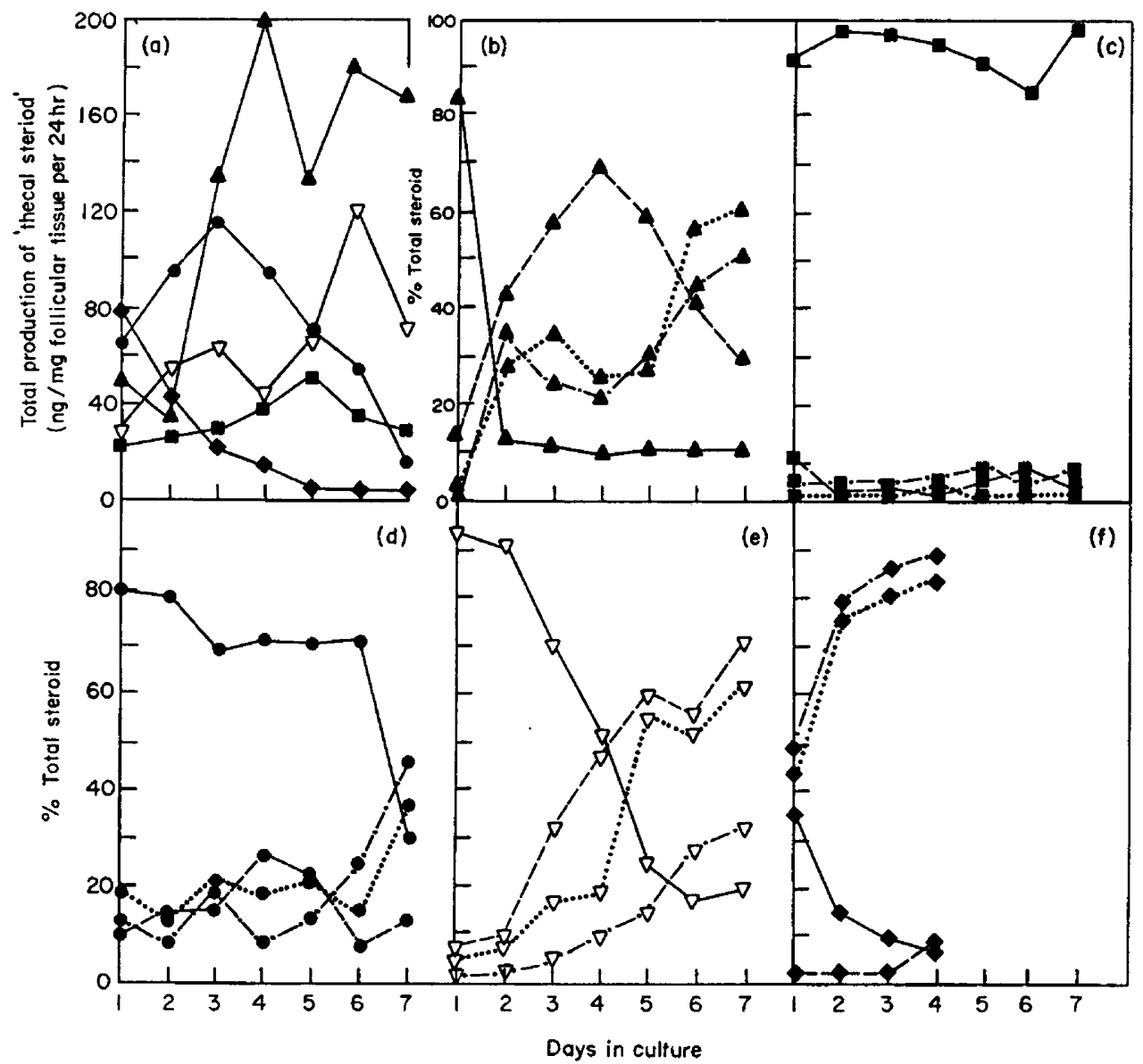

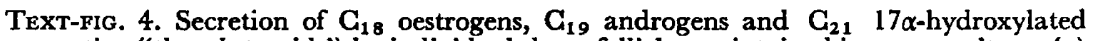
progestins ('thecal steroids') by individual sheep follicles maintained in organ culture. (a) Total secretion of 'thecal steroids' by follicles obtained at the following stages of the oestrous cycle: $\triangle$, Day 4; $\square$, Day 8 ; $\bullet$, Day $14 ; \nabla$, Day 15 ; $\diamond$, oestrus. (b)-(f) Available substrates for --- , aromatase; $-.-\cdot-$, desmolase and $\cdots \cdots$, , isomerase enzyme systems, expressed as a percentage of total 'thecal steroid' produced. Included are values for oestrogen (—

produced increased amounts of substrate for the intermediate enzymes but the total steroid production was as high as in follicles explanted at Day 8.

\section{DISGUSSION}

The combination of tissue culture techniques and a comprehensive steroid assay 
system has enabled us to study the biosynthetic capacity of the various discrete tissue components within the ovary. The largest follicle in each animal is the principal source of follicular oestrogen secretion (Moor, 1973) and consequently these initial studies have been confined to this class of follicle.

The lack of an assay capable of measuring rapidly the wide range of steroids produced by follicles has been a major limitation to our work in the past. The assay technique described in this paper overcomes this limitation and has the advantage of being not only rapid but also sensitive and comprehensive. It is based upon three standard group-specific competitive protein-binding assays coupled with enzymatic and chemical modifications to convert non-reactive substances to reactive ones. Specificity has been conferred on the assay through the use of thin layer and alumina column chromatography.

The validity of the assay has been checked by the use of gas-liquid chromatography and more recently by using radioactive labelling techniques coupled with rigorous identification by means of radioisotope dilution procedures (R. F. Seamark, J. Gardner and R. M. Moor, unpublished observations). These procedures have provided conclusive proof that all the steroids described in this paper are secreted by sheep ovarian follicles in organ culture. It is nevertheless accepted by us that our analytical methods do not completely satisfy the most rigorous criteria of specificity for all the steroids determined. The term 'fraction' has been used to denote those steroids in which the specificity obtained is open to doubt; the clearest example of this is the 'dehydroepiandrosterone fraction', in which interference by other $\mathrm{C}_{19}$-17-oxosteroids may be anticipated. In these cases, the steroid levels are presented not as an absolute measure of steroid output but rather as a measure of the maximum level of each steroid produced.

We interpret our results as suggesting that the oestrogens, androgens and $17 \alpha-$ hydroxylated progestins are secreted by the cells of the theca interna while the membrana granulosa is the principal source of progesterone, $20 \alpha$-hydroxypregn-4-en-3-one and pregnenolone. This division is based upon the fact that isolated granulosa cells maintained in tissue culture produced only non- $17 \alpha$ hydroxylated progestins. Moreover, progesterone and its $20 \alpha$-dihydro derivative are produced by intact follicles only after the membrana granulosa has undergone clear morphological luteinization. In all other follicles, i.e. those in which the thecal cells are large and the membrana granulosa is composed of nonluteinized small cells, oestrogens, androgens and $17 \alpha$-hydroxylated progestins are produced but no progesterone or 20 $\alpha$-hydroxy-pregn-4-en-3-one is formed. These results are supported by the fact that before luteinization, $3 \beta$-hydroxysteroid dehydrogenase, a key enzyme in steroid biosynthesis, is confined to the theca interna; the acquisition of this enzyme by the membrana granulosa coincides with the luteinization of these cells and the early production of progesterone (Hay \& Moor, 1973). Our results are therefore compatible with the 'two-cell' hypothesis of Short (1964) and indicate that the transformation of the follicle from an organ producing oestrogen, androgen and 17 $\alpha$-hydroxylated

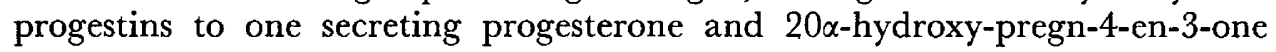
reflects a transfer of steroid synthetic capacity from the theca interna to the membrana granulosa. 
The pattern in which steroids are secreted by follicles explanted during the luteal phase of the cycle suggests that the most likely route of 'thecal' steroid biosynthesis involves the following steps:

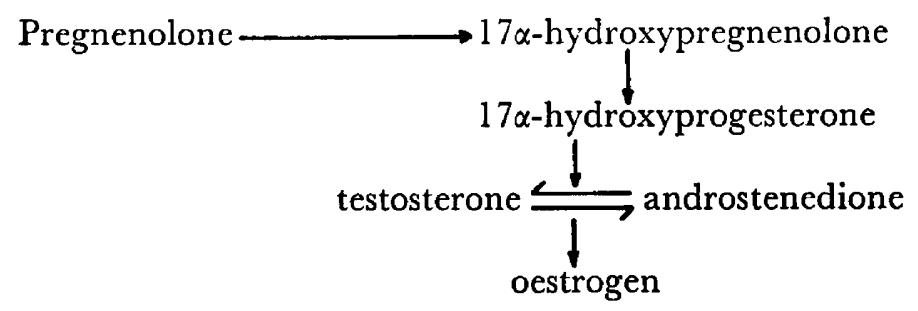

The possible involvement of dehydroepiandrosterone in the sequence of synthetic events is not clear due to the poor specificity of the assay for this compound.

Transference of steroidogenic potential from the theca interna to the membrana granulosa resulted in an overall increase in the mass of steroid produced. This increase is probably the result of the lesser requirements, in terms of reducing equivalents and oxygen, of progestin as opposed to oestrogen synthesis.

The steroidogenic capacity of individual follicles in culture was markedly affected by the endocrine influence to which they were subjected before explantation. Thus, while the total daily output of steroid by cultured follicles remained constant or even increased over the 7 days in vitro, the relative amount of each steroid produced was determined by the stage of the cycle at which the follicles were obtained. The release of high levels of oestrogen and androgen characterized follicles explanted on Day 4; the marked change in the pattern of steroid production during the period of culture can be interpreted chiefly in terms of impeded aromatase activity. These follicles probably developed under the influence of the high levels of gonadotrophin circulating at oestrus and if left in vivo would have been the principal contributors of the oestrogen and androgen secreted into the ovarian venous blood on Days 4 and 5 of the cycle. By contrast, follicles obtained on Day 8 produced only oestrogen throughout the period of culture. This stable pattern adequately reflected the overall stability of the ovary during the progesterone-dominated mid-luteal phase of the cycle and imply that none of the enzyme systems was impeded at this stage. By Day 14 to 15 luteal influence wanes and the secretion of oestrogen increases. This situation was reflected in the high levels of oestrogen released by follicles explanted at this time. In follicles obtained just before oestrus (late Day 15) a decline in oestrogen production occurred followed by large but transitory peaks, first of androgen and then of $17 \alpha$-hydroxylated progestin production. This sequence of steroid changes occurs also in follicles exposed to LH in vitro (J. E. A. McIntosh and R. M. Moor, unpublished observations) and suggests that the aromatase system is the initial rate-limiting step in steroid biosynthesis in follicles undergoing transformation from oestrogen to progesterone secretors. The large output of androgen during transformation could possibly result in subsequent impedance of the desmolase and isomerase systems in the thecal cells. In follicles explanted 6 to $12 \mathrm{hr}$ after the endogenous LH peak (oestrous group), oestrogen production was minimal and the loss of 17,20-side-chain-cleavage 
capacity (i.e. desmolase activity) was the most significant limiting feature at this time.

The main difference between the pattern of steroids produced by follicles in vivo and those maintained in organ culture is that the reduced rather than the oxidized form of each steroid is generally secreted by follicles in vitro. It is possible that this is due to the effect exerted by the culture conditions on the redox state of the follicular tissues. These conditions were selected on the basis of electron microscopic and other morphological criteria and on the capacity of follicles to retain their ability to secrete high levels of immunoreactive oestrogens in culture. As the antibody used in the radioimmunoassay of oestrogen measured $17 \beta$-oestradiol rather than oestrone, it is likely that culture conditions favouring the formation of $17 \beta$-oestradiol rather than its redox partner, oestrone, were chosen. Presumably, these same conditions have also selectively favoured the secretion of other steroids in the reduced form. This possibility is at present being investigated. However, by measuring both partners in each redox pair, as has been routinely done in this study, the overall flux of steroids through the biosynthetic pathways can be adequately assessed.

\section{ACKNOWLEDGMENTS}

The authors wish to acknowledge the skilled technical assistance of $\mathrm{Mr} \mathrm{D}$. Green. We are grateful to Professor T. R. R. Mann for his advice during the preparation of this paper.

This study was supported in part by a grant to one of us (R.F.S.) from the National Medical Research Council of Australia.

The non-radioactive steroids from the Medical Research Council's reference collection were obtained by courtesy of $\mathrm{Dr}$ D. N. Kirk.

\section{REFERENCES}

BAIRD, D. T. (1968) A method for the measurement of oestrone and oestradiol-17 $\beta$ in peripheral human blood and other biological fluids. F. clin. Endocr. Metab. 28, 244.

Cox, R. I., Mattner, P. E. \& Thorburn, G. D. (1971) Changes in ovarian secretion of oestradiol-17 $\beta$ around oestrus in the sheep. F. Endocr. 49, 345.

HAY, M. F. \& Moor, R. M. (1973) The Graafian follicle of the sheep: relationships between gonadotrophins, steroid production, morphology and oocyte maturation. Annls Biol. anim. Biochim. Biophys. 13, 241.

Moor, R. M. (1973) Oestrogen production by individual follicles explanted from ovaries of sheep. 7. Reprod. Fert. 32, 545 .

Moor, R. M., Hay, M. F., MaIntosh, J. E. A. \& CAldwell, B. V. (1973) Effect of gonadotrophins on the production of steroids by sheep ovarian follicles cultured in vitro. F. Endocr. 58, 599.

MURphy, B. E. P. (1967) Some studies of the protein-binding of steroids and their application to the routine micro and ultra-micro measurement of various steroids in body fluids by competitive protein-binding radioassay. 7. clin. Endocr. Metab. 27, 973.

Seamark, R. F., Herriot, D. \& Nancarrow, G. D. (1972) Partial purification and properties of an NADP 20 $\alpha$-hydroxy steroid oxido-reductase from foetal sheep blood. 7. Endocr. 52, xiv.

Short, R. V. (1964) Ovarian steroid synthesis and secretion in vivo. Recent Prog. Horm. Res. 20, 303.

Strott, G. A., Bermudez, J. A. \& Lipsett, M. B. (1970) Blood levels and production rate of 17-hydroxy pregnenolone in man. F. clin. Invest. 49, 1999.

Vermuelen, A. \& Verdonck, L. (1970) Testosterone assays by competitive protein binding. Acta endocr., Copenh. Suppl. 147, 239. 